The data sheet for acyclovir currently recommends $5 \mathrm{mg} / \mathrm{kg}$ eight hourly for normal patients and $10 \mathrm{mg} / \mathrm{kg}$ for those who are immunocompromised. After our experience with the first patient the second and third were given a higher dose. The fourth patient may have avoided pneumonitis through its early use. Varicella zoster is known to be less sensitive than herpes simplex virus. Reversible impairment of renal function is the most important adverse effect, resulting from renal deposition when hydration or renal function is inadequate. Acyclovir should be infused slowly with a litre of fluid for each gram of the drug. ${ }^{4}$ Animal studies have not shown adverse effects from acyclovir on the fetus, and treatment of disseminated herpes simplex in pregnancy in humans has been reported with no apparent fetal damage. ${ }^{5}$

Our experience suggests that chickenpox in pregnancy is sufficiently hazardous to merit admission to hospital and early treatment with acyclovir, especially if pulmonary damage is suspected. Possible harmful effects to the fetus must be considered but do not seem to have occurred in our patients, who received treatment in the second and third trimesters.

We thank Dr I W Pinkerton of Ruchill Hospital and Dr W P Black of the Royal Maternity Hospital, Glasgow, for permission to study their patients and to $\mathrm{Mr} \mathrm{J} \mathrm{K}$ Roberts of Wellcome Foundation for his advice on the use of acyclovir in pregnancy.

1 Paryani SG, Arvin AM. Intrauterine infection with varicella zoster virus after maternal varicella. N Engl f Med 1986;314:1542-6.

2 Ellis ME, Neal KR, Webb AK. Is smoking a risk factor for pneumonia in adults with chickenpox? BrMed F 1987;294:1002.

3 Evans EB, Pollock TM, Cradock-Watson JE, Ridehalgh MKS. Human anti-chickenpox immunoglobulin in the prevention of chickenpox. Lancet 1980;i:355-6.

4 Balfour HH. Acyclovir therapy for herpes zoster-advantages and adverse effects. FAMA 1986;255:387-8.

5 Greffe BS, Dooley SL, Deddish RB, Krasney HC. Transplacental passage of acyclovir. 7 Pediatr 1986;108:1020-1

(Accepted 8 October 1987)

Department of Infectious Diseases, Ruchill Hospital, Glasgow G20 9NB

K BOYD, MRCP, registrar

E WALKER, MRCP, MRCGP, lecturer

Correspondence to: Dr Walker.

\section{Failure of salt to increase starch digestibility and glycaemic response}

The hypothesis that dietary starch is digested more rapidly when it is taken together with salt is plausible but rests only on a report that six normal subjects tended to have higher plasma glucose or insulin concentrations when they breakfasted on lentils or bread with added salt. ${ }^{1}$ Another small study found no difference in glycaemia when salt was added to glucose or macaroni test meals. ${ }^{2}$ We tested this hypothesis in a larger group of subjects, measuring insulin as well as glucose responses and also estimating the escape of undigested starch from the small intestine. The test meal was designed to be a realistic, mixed meal.

\section{Subjects, methods, and results}

Thirteen healthy non-obese volunteers (aged 20-69) took part in the study. Four were male medical students and nine (four men) had normally functioning ileostomies after a curative colectomy for ulcerative colitis performed at least one year beforehand. No subject was taking any medication.

Test meals $(52 \cdot 4 \mathrm{~g}$ carbohydrate, $17 \cdot 1 \mathrm{~g}$ protein, $17 \cdot 1 \mathrm{~g}$ fat) consisted of $21 \mathrm{~g}$ Cheddar cheese, $8 \mathrm{~g}$ butter, $300 \mathrm{ml}$ tea, $50 \mathrm{~g}$ milk, and a baked wholewheat bread scone containing $50 \mathrm{~g}$ carbohydrate. The scones consisted of $76 \mathrm{~g}$ finely ground wholewheat flour, $0.75 \mathrm{~g}$ sodium bicarbonate, $1.5 \mathrm{~g}$ cream of tartar, and $50 \mathrm{~g}$ water; the salted scones contained in addition $4.25 \mathrm{~g}$ of sodium chloride. The total sodium contents of the salted and unsalted meals were $87 \mathrm{mmol}$ and $16 \mathrm{mmol}$ respectively. All the scones were baked undisturbed at $210^{\circ} \mathrm{C}$ for 15 minutes in the same oven. After baking they were cooled then stored at $-18^{\circ} \mathrm{C}$. When required they were thawed overnight.

After a 12 hour overnight fast venous blood samples were taken in the fasting state and $10,20,30,40,50,60,75,90,120$, and 180 minutes after the test meal (except in one subject with an ileostomy in whom venous access was not possible). Ileostomy effluent was collected in hourly samples for eight hours after the test meal and immediately stored at $-20^{\circ} \mathrm{C}$ until the time of assay. Test meals were administered in random order and were consumed steadily over 20 minutes under supervision. Plasma glucose concentrations were measured in an autoanalyser by the glucose oxidase method. Plasma insulin was estimated by radioimmunoassay. ${ }^{3}$ Starch in the homogenised ileostomy effluent was measured as the glucose released during incubation with amyloglucosidase. ${ }^{4}$ Areas under the insulin and glucose concentration curves were estimated as those above the zero time point. Student's paired $t$ test was used in comparing the response to the salted and unsalted meals. Results are expressed as means (and standard errors). The study was approved by the Bristol and Weston health district ethical committee.

The meals containing unsalted and salted bread produced no significant differences in plasma glucose concentration at any postprandial time point or in area under the glucose concentration curve (table). In addition neither individual postprandial plasma insulin values nor area under the insulin concentration curve differed significantly between the two meals (table). If it had any effect, salt tended to reduce the metabolic response to starch.

Plasma glucose and insulin responses to mixed meals based on bread with and without added salt in 12 subjects. Results are means (and standard errors)

\begin{tabular}{lcc}
\hline & No salt & Salt \\
\hline Fasting glucose $(\mathrm{mmol} / \mathrm{l})$ & $3 \cdot 85(0 \cdot 15)$ & $3 \cdot 97(0 \cdot 14)$ \\
Peak glucose $(\mathrm{mmol} / \mathrm{l})$ & $5 \cdot 95(0 \cdot 26)$ & $5 \cdot 90(0 \cdot 20)$ \\
Area under glucose curve $(\mathrm{mmol} / \mathrm{l} \mathrm{min})$ & $145(22)$ & $105(17)$ \\
Fasting insulin $(\mathrm{mU} / \mathrm{l})$ & $5 \cdot 00(1 \cdot 00)$ & $6 \cdot 00(1 \cdot 00)$ \\
Peak insulin $(\mathrm{mU} / \mathrm{l})$ & $49(5)$ & $49(6)$ \\
Area under insulin curve $(\mathrm{mU} / \mathrm{l} \mathrm{min})$ & $3728(411)$ & $3059(287)$ \\
\hline
\end{tabular}

\section{Comment}

These findings make it unlikely that salt increases the rate of starch digestion to any important extent, at least in the context of a normal mixed meal.

Starch output in the subjects who had had ileostomies tended to be higher after the meals containing salted bread, not lower as predicted by the hypothesis, but this difference was not significant $(502(216) \mathrm{mg}$ glucose $v$ 397 (164) mg glucose, $n=9$ ). Clearly, salt does not reduce the physiological malabsorption of starch which occurs in healthy subjects. ${ }^{45}$ This again makes it unlikely that salt affects starch digestion to an important extent in real life. In the light of these data, salt restriction is unlikely to help control postprandial glycaemia in diabetics. ${ }^{1}$

We thank Miss A Moffatt and the chemical pathology laboratory, Bristol Royal Infirmary, for their expert technical help. The study was supported by the Bristol and Weston Health Authority.

1 Thorburn AW, Brand JC, Stewart Truswell A. Salt and the glycaemic response. Br Med $\mathcal{F}$ 1986;292:1697-9.

2 Gans ROB, Heine RJ, Donker AJM, van der Veen EA. Influence of salt on glycaemic response to carbohydrate loading. $\mathrm{Br}$ Med $\mathcal{F}$ 1987;294:1252-3.

3 Oettle GJ, Emmett PM, Heaton KW. Glucose and insulin responses to manufactured and wholefood snacks. Am F Clin Nutr 1987; 45:86-91.

4 Chapman RW, Sillery JK, Graham MM, Saunders DR. Absorption of starch by healthy ileostomates: effect of transit time and of carbohydrate load. Am 7 Clin Nutr 1985;41:1244-8.

5 Anderson IH, Levine AS, Levitt MD. Incomplete absorption of the carbohydrate in all-purpose wheat flour. N Engl f Med 1981;304:891-2.

(Accepted 6 October 1987)

University Department of Medicine, Bristol Royal Infirmary, Bristol BS2 8HW LUKE J D O'DONNELL, MB, MRCPI, medical registrar

PAULINE M EMMETT, BSC, senior dietitian

KENNETH W HEATON, MD, FRCP, reader in medicine

Correspondence to: Dr Heaton.

\section{Cholesterol embolism in a renal graft after treatment with streptokinase}

The clinical features of cholesterol embolism in the kidney have been well delineated. ${ }^{1}$ We report a case of acute renal graft failure due to cholesterol emboli. We further suggest that fibrinolytic treatment caused the disease and draw attention to this potential complication of an increasingly popular treatment of myocardial infarction..$^{23}$

\section{Case report}

A 56 year old man was admitted to hospital with chest pain that had lasted four hours. Nineteen years earlier he had received a cadaver kidney transplant after a 20 year history of chronic glomerulonephritis with hypertension. No rejection occurred. Serum creatinine concentration was stable at $150 \mu \mathrm{mol} / \mathrm{l}$. Maintenance 